\title{
Composition and diversity of Ephemeroptera (Insecta) nymph communities in the middle section of the Jacuí River and some tributaries, southern Brazil
}

\author{
Ana Emilia Siegloch ${ }^{1}$, Claudio Gilberto Froehlich ${ }^{1} \&$ Carla B. Kotzian $^{2}$
}

\author{
1. Departamento de Biologia, Faculdade de Filosofia, Ciências e Letras de Ribeirão Preto, Universidade de São Paulo, 14040-901 Ribeirão \\ Preto, SP, Brazil. (siegloch@usp.br, cgfroeh@usp.br) \\ 2. Departamento de Biologia, Universidade Federal de Santa Maria, Caixa Postal 5057, 97105-900 Santa Maria, RS, Brazil. \\ (mickey@ccne.ufsm.br)
}

\begin{abstract}
The taxonomic composition and diversity of assemblages of Ephemeroptera nymphs of four lotic environments in the central region of State of Rio Grande do Sul, a subtropical area in southern Brazil, were evaluated. Samplings were done monthly, with a Surber sampler, from June 2001 to May 2002, in the Jacuí River and three of its tributaries. The total number of nymphs collected in the four sampling sites was 11,007 in five families and 19 genera, of these, 11 are new records for the State. The highest diversity occurred in Point $4\left(\mathrm{H}^{\prime}=2.41\right)$ and the lowest in Point $2\left(\mathrm{H}^{\prime}=1.69\right)$. Point 4 had the highest environmental stability, conservation of the riparian vegetation and the lowest anthropic impact, while Point 2 presented a large environmental simplification due to a direct anthropic influence (e.g. domestic sewerage, trampling by cattle). The diversity of nymphs observed in the total area is high, compared to the estimated maximum theoretical diversity; a result of the high evenness and richness recorded. Rarefaction curves, calculated for a sample of 1,018 specimens, showed a similar expectation of richness for the four sampling sites. This result seems to be associated with the overall environmental homogeneity of the region caused by long-term alterations (land use and deforestation). In summary, higher diversity of Ephemeroptera nymph assemblages seems to be associated with habitat complexity, a good vegetation cover and a lower anthropic influence.
\end{abstract}

KEY WORDS. Ephemeroptera, nymphs, taxonomic composition, diversity, southern Brazil.

\begin{abstract}
RESUMO. Composição taxonômica e diversidade das comunidades de ninfas de Ephemeroptera (Insecta) do curso médio do Rio Jacuí e afluentes, sul do Brasil. Foram analisadas a composição taxonômica e a diversidade das ninfas de Ephemeroptera de quatro ambientes lóticos localizados na região central do Rio Grande do Sul, região subtropical do sul do Brasil. As coletas foram realizadas mensalmente entre junho de 2001 e maio de 2002 no Rio Jacuí e em três afluentes, com um amostrador do tipo Surber. Foram coletadas 11.007 ninfas, distribuídas em cinco famílias e 19 gêneros, sendo 11 novos registros para o Estado. A maior diversidade foi encontrada no Ponto $4\left(H^{\prime}=2,41\right)$ e a menor no Ponto $2\left(H^{\prime}=1,69\right)$. O Ponto 4 apresenta maior estabilidade ambiental, conservação da vegetação ciliar e menor ação antrópica; enquanto o Ponto 2 possui grande simplificação ambiental, proveniente da influência antrópica direta no local (e.g. esgoto doméstico, pisoteio de gado). A diversidade de ninfas na área total foi alta, comparada com a diversidade teórica máxima estimada, resultante da alta riqueza e equidade registradas. As curvas de rarefação evidenciaram expectativa de riqueza relativamente semelhante para os pontos, em uma amostra comparável de 1.018 indivíduos. Este resultado provavelmente está associado à semelhança dos locais devida à continuada alteração ambiental da região (uso do solo e desmatamento). No geral, a maior diversidade das comunidades de ninfas de Ephemeroptera parece ser resultante da complexidade do hábitat, maior cobertura vegetal e menor ação antrópica.
\end{abstract}

PALAVRAS-CHAVE. Ephemeroptera, ninfas, composição taxonômica, diversidade, sul do Brasil.

Ephemeroptera nymphs are important components of freshwater benthic communities both by their abundance and diversity as by the wide variety of habitats they occupy (MerRITT \& Cummins, 1996; SAlLES et al., 2004b, DomíngUEZ et al., 2006). About 3,000 species of mayflies in ca. 375 genera are known worldwide (Domínguez et al., 2006). Mayflies are very diverse in the Neotropical Region, their nymphs being commoner in low to medium-order streams with stony bottoms. From Brazil, 66 genera and 170 species have been reported. The best known regions are the Southwest and North, followed by the South (SAlles et al., 2004b; Dias et al., 2005; Siegloch et al., 2006, Polegatto \& Batista, 2007).

Among published papers, most emphasize taxonomic aspects, but more recently several important contributions have been made on the ecology of running waters invertebrate communities, including the Ephemeroptera (Melo et al., 2002; FroeHLich \& OliveIRA, 1997; Oliveira et al., 1997; Oliveira \& Froenlich, 1997;
BISPO et al., 2001; BAPTISTA et al., 2001, 2006). For the State of Rio Grande do Sul, no studies on Ephemeroptera nymph communities have been made. Previous studies concern macroinvertebrate communities of the Rio dos Sinos basin (STERNERT et al., 2002; SANTOS et al., 2003), of the Rio Tainhas and Rio Taquara (BuENo et al., 2003), all in the northeast of the State, and in streams of the middle Jacuí River basin, in the central part of the State (AYRESPeres et al., 2006). In this area, ecological studies on the communities of Heteroptera (NERI et al., 2005) and Trichoptera (SPIES et al., 2006) have also been done.

In this context, considering the importance of faunistic surveys for obtaining basic information for biological and ecological studies and the poor knowledge of the mayfly fauna of State of Rio Grande do Sul, the aims here were to ascertain the taxonomic composition and the diversity of the mayfly nymph communities of the middle course of the Jacuí River basin. 


\section{MATERIAL AND METHODS}

The area is located in the central region of State of Rio Grande do Sul, in the transition zone between the physiographic regions known as the Lower northeastern Slope and the Central Depression, with altitudes varying from 50 to $500 \mathrm{~m}$ a.s.l. (PEREIRA et al., 1989). The climate is humid subtropical with hot summers (Cfa of Köppen) (MAluf, 2000), with a rather uniform rainfall along the year, oscillating between 1,500 and $1,750 \mathrm{~mm}$ and the mean annual temperature varies between 18 and $20^{\circ} \mathrm{C}$, with lowest temperatures in June and July (PEREIRA et al., 1989). The vegetation of the Jacuí River valley and its tributaries belongs to the Seasonal Deciduous Forest, part of the Atlantic Forest Domain (Marcuzzo et al., 1998). At present this vegetation is much degraded and in different succession stages, from low shrubs to secondary growths distributed sparsely; likewise, along rivers, the riparian wood (DuRLo et al., 1982; LONGHI et al., 1982; MARCHIORI et al., 1982).

In the middle course of the Jacuí River a dam (U.H.E. Dona Francisca, $29^{\circ} 26^{\prime} 50^{\prime \prime} \mathrm{S}, 53^{\circ} 16^{\prime} 50^{\prime \prime} \mathrm{W}$ ) was built and began operating in October 2000. The reservoir flooded 1,337 ha of land, increasing environmental stress.

Samplings were done monthly from June 2001 to May 2002 in the Jacuí River and three of its tributaries within the area close to the reservoir (Fig. 1). The sampling points are: Point 1 (2942’29”S, 5317’02”W) - Jacuí River,

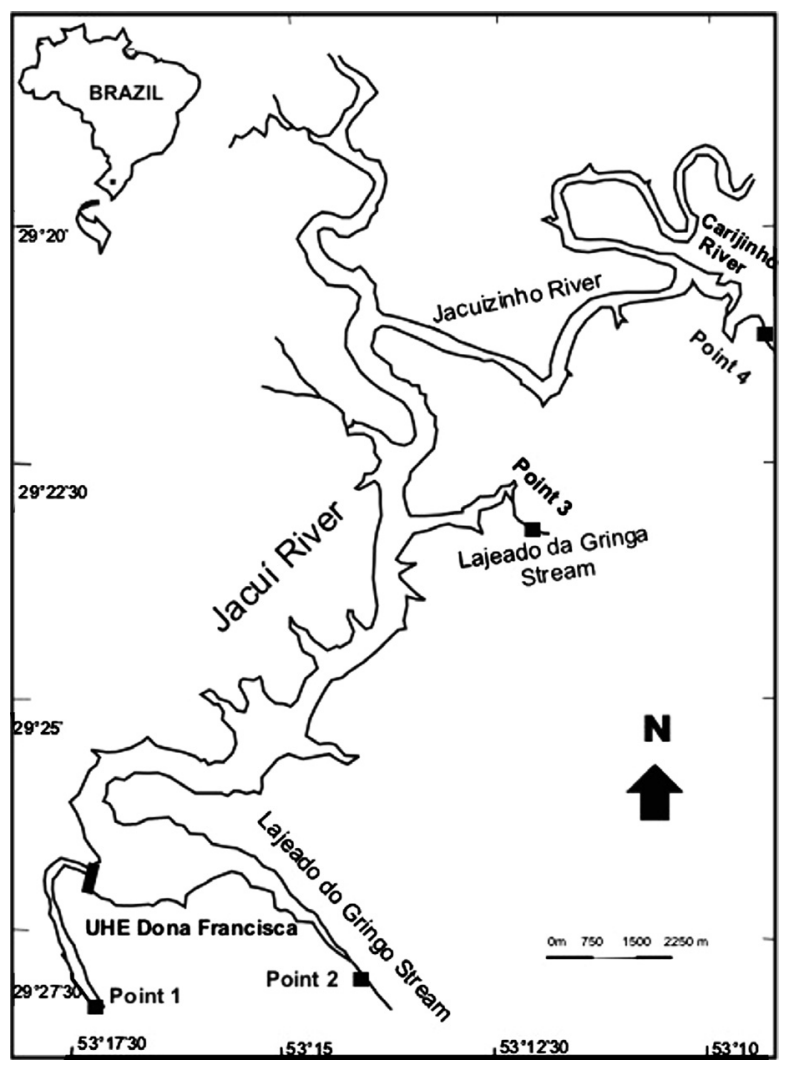

Fig.1. Map of the study area indicating the sampling points in the Jacuí River middle section and in three tributaries, situated in central region of the State of Rio Grande do Sul. at an altitude of $70 \mathrm{~m}$ and ca. $2 \mathrm{~km}$ downstream of the dam in a 7th order stretch, in Agudo municipality. A few samplings were done in a bay formed in the left bank during high waters. Daily fluctuations in water level, caused by the dam operations, are a peculiarity of this point. The area is open, with sparse riparian shrubs. Point 2 (292'03"S, 53 ${ }^{\circ} 13$ '28' W) - Lajeado do Gringo River, a 4th order tributary at an altitude of $136 \mathrm{~m}$, Ibarama municipality. Riparian vegetation is restricted to one bank and the stretch has been much altered by human occupation; the point stands at the back of a farm house. Point 3 (2922'57' S, 5312'08'” W) - Lajeado da Gringa River, a 3rd order tributary at an altitude of $100 \mathrm{~m}$, Ibarama municipality. A narrow riparian shrubby vegetation is present at both banks and, in the river, the stony substratum is frequently covered by the macrophyte Podostemum (Podostemaceae). Point 4 (29 21'17'S, $\left.53^{\circ} 09^{\prime} 13^{\prime \prime} \mathrm{W}\right)$ - Carijinho River, a 4th order tributary at an altitude of $111 \mathrm{~m}$, Arroio do Tigre municipality. The riparian vegetation is in a relatively good state and Podostemum occurs attached to cobbles in the river.

For characterizing the degree of anthropic influence a scale of three subjective steps was used: 1 - low, 2 - medium, 3 - high intensity; for the vegetation cover a similar scale was used: 1 - relatively good conditions, 2 - shrub present on both banks, 3 - greatly altered (OliveIRA et al., 1999). For turbidity, a scale from 1 - low to 2 - high, was based on a subjective evaluation (Tab. I). The hydrologic classification followed STRAHLER (1957).

Nymphs were collected in riffles with a Surber sampler of $0.36 \mathrm{~m}^{2}$ in area and a $1 \mathrm{~mm}$ mesh. In each point three sampling units were taken, two near the bank and one at the centre, except in Point 1 , where the units were collected near the left bank or, when the water level was high, in a bay. When the macrophyte Podostemum was attached to stones in the sampling area, it was scraped off and preserved in ethanol at 80\%. Sampled material was sorted in the laboratory, identified with the aid of a stereomicroscope and counted. For the identification of the nymphs were used the keys of Domínguez et al. (2006) and SALLES et al. (2004a). Nymphs of Leptohyphidae were identified to species with the aid of a specialist and specialized bibliography.

Voucher specimens are deposited in the Invertebrate Collection of the Zoology Section of the Department of Biology, Federal University of Santa Maria (UFSM), State of Rio Grande do Sul, and in the Museum of Zoology, University of São Paulo (MZSP), State of São Paulo.

The diversity was evaluated by Shannon-Wiener (H') Diversity Index and by Pielou's Evenness Index (E), utilizing programs Biodiversity Pro and Ecological Methodology (McAlecee et al., 1997; KreBs, 1999). The genera richness among the sites was compared by $T$ test, described by Poole (1974), utilizing program Past 1.34 (HAMMER et al., 2003).

Rarefaction curves were built for the sampling points utilizing a method similar to those of HURLBERT (1971) and SimberLof (1972) that selected randomly K 
individuals from the samples. The number of genera was estimated for $\mathrm{K}$ individuals and the procedure was iterated 1,000 times. The mean of the number of genera obtained was considered as the estimated richness for $\mathrm{K}$ individuals. The method also allows to calculate the variance and confidence intervals, in this case at $95 \%$ significance. The program EcoSim7 (Gotelli \& ENTSMigen, 2003) was used.

The accumulated species richness was estimated by collector curves by Coleman method (CoLEMAN, 1981), obtained from 100 curves generated by random addition of samples, with help of the program EstimateS 7 (Colwell, 2004). According to Colwell \& Coddington (1994), this method avoids fluctuations in the curves when samples are added and is excellent to evaluate how much the survey approaches the total richness of the area. Obtained species richness depends not only on the characteristics of the area but also on sampling effort. When an increase in the sampling effort does not result in an increase in the number of species, the total richness of the area has been attained (SANTOS, 2003).

\section{RESULTS}

A total of 11,007 nymphs were collected, belonging to 19 genera in five families (Tab. II). Some Leptohyphidae were identified to species: Leptohyphes plaumanni Allen, 1967, Tricorythodes santarita Traver, 1959, Tricorythopsis yacutinga Molineri, 2001 and Tricorythopsis gibbus Allen, 1967.

The lowest abundance was presented by Point 1 (1,018 individuals) and the highest by Point $3(4,920$ individuals). It is important to emphasize that in July 2001 no sampling was done in Point 1 due to a spate. The richness obtained for the four sites was very similar, but was slightly higher in Point 4 (17 genera) and lower in Point 2 (14 genera) (Tab. II).

Leptophlebiidae presented the largest number of genera, eight, and also a good proportion of collected nymphs, 27.8\%. Leptohyphidae and Baetidae had four genera each, and their share of collected nymphs were 38.85 and $31.38 \%$, respectively.

There was no strong dominance of any genus. The most abundant were Traverhyphes Molineri, 2001 (13.37\% of the total), Baetodes Needham \& Murphy, 1924 (13.35\%) and Americabaetis Kluge, 1992 (12.94\%); the rarer ones were Asthenopus Eaton, 1871 (0.02\%), Hydrosmilodon Flowers \& Domínguez, 1992 (0.01\%) and Massartella Lestage, $1930(0.01 \%)$.

The overall diversity of mayfly nymphs $\left(\mathrm{H}^{\prime}=2.47\right)$ represented $87.28 \%$ of the maximum theoretical diversity $\left(\mathrm{H}_{\max }=2.83\right)$. Point 4 had the largest diversity index and evenness values $(p<0.05)$ (Tab. III). Along the year, diversity and evenness values oscillated strongly, especially those of Points 1 and 2; these points, on the whole, showed the lowest values and a sharp drop in November (Point 1), and in October and November (Point 2). Point 4 kept the highest values, except in April and May (Figs. 2, 3).
Rarefaction curves calculated for 1,018 individuals (total abundance of Point 1) showed an expected richness of 16 genera for Point 1, 15.7 genera for Point 4, 15.2 genera for Point 3 and 14 genera for Point 2. Even with the lower expected value for Point 2 , the expected genera richness for all points were similar, especially when considering the confidence intervals (Figs. 4, 5).

Examining the genera accumulation curves, it may be seen that only the curve of Point 2 stabilized from January 2002 on. For the other points the asymptote was not reached, particularly for Point 1 , and that the confidence intervals maintained large values to the end (Fig. 6).

Table I. Physical characterization of the four sampling points between June 2001 and May 2002 in the middle section of the Jacuí River and tributaries, southern Brazil. (1, low; 2, medium; 3, high intensity for the vegetation cover and anthropic influence; for turbidity, a scale from 1 , low to 2 , high intensity).

\begin{tabular}{lccccc}
\hline Point & Sites & $\begin{array}{c}\text { Order of } \\
\text { stream }\end{array}$ & $\begin{array}{c}\text { Degree of } \\
\text { canopy } \\
\text { cover }\end{array}$ & $\begin{array}{c}\text { Degree of } \\
\text { anthropic } \\
\text { influence }\end{array}$ & $\begin{array}{c}\text { Degree of } \\
\text { turbidity }\end{array}$ \\
\hline 1 & Jacuí River & $7^{\mathrm{a}}$ & 1 & 3 & 2 \\
2 & Lajeado do Gringo & $4^{\mathrm{a}}$ & 2 & 3 & 1 \\
3 & Lajeado da Gringa & $3^{\mathrm{a}}$ & 2 & 2 & 1 \\
4 & Carijinho River & $4^{\mathrm{a}}$ & 3 & 1 & 1 \\
\hline
\end{tabular}

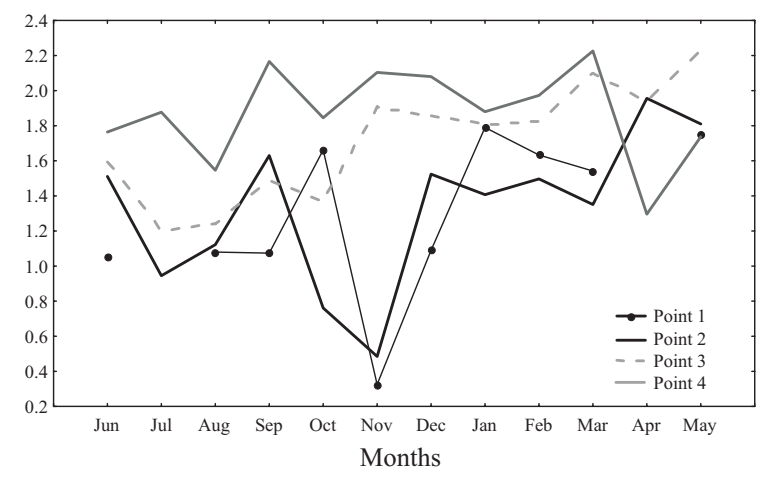

Fig. 2. Diversity index of Shannon-Wiener registered between June 2001 and May 2002 in the middle section of the Jacuí River and tributaries, southern Brazil.

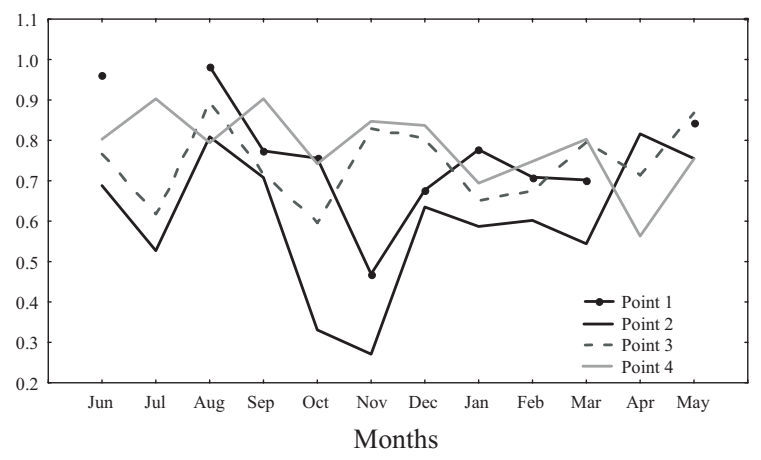

Fig. 3. Evenness index registered between June 2001 and May 2002 in the middle section of the Jacuí River and tributaries, southern Brazil. 
Table II. Taxonomic composition and genera abundance of the Ephemeroptera nymphs communities sampled between June 2001 and May 2002 in the Jacuí River and three tributaries, southern Brazil (* new genera registered for State of Rio Grande do Sul).

\begin{tabular}{|c|c|c|c|c|c|}
\hline Taxa & Point 1 & Point 2 & Point 3 & Point 4 & Total \\
\hline \multicolumn{6}{|l|}{ BAETIDAE } \\
\hline Americabaetis Kluge, 1992 & 19 & 82 & 1049 & 274 & 1424 \\
\hline Baetodes Needham \& Murphy, 1924* & 17 & 823 & 440 & 189 & 1469 \\
\hline Camelobaetidius Demoulin, 1966 & 33 & 14 & 172 & 168 & 387 \\
\hline Cloeodes Traver, 1938* & 43 & 35 & 45 & 51 & 174 \\
\hline \multicolumn{6}{|l|}{ CAENIDAE } \\
\hline Caenis Stephens, 1835 & 1 & 11 & 120 & 11 & 143 \\
\hline \multicolumn{6}{|l|}{ LEPTOHYPHIDAE } \\
\hline Leptohyphes Eaton, $1882 *$ & 1 & 307 & 149 & 158 & 615 \\
\hline Traverhyphes Molineri, 2001* & 351 & 55 & 779 & 287 & 1472 \\
\hline Tricorythodes Ulmer, 1920 & 23 & 23 & 765 & 77 & 888 \\
\hline Tricorythopsis Traver, 1958 & 26 & 17 & 588 & 671 & 1302 \\
\hline \multicolumn{6}{|l|}{ LEPTOPHLEBIIDAE } \\
\hline Farrodes Peters, $1969^{*}$ & 147 & 22 & 39 & 85 & 293 \\
\hline Homothraulus Demoulin, $1955^{*}$ & 215 & 20 & 49 & 238 & 522 \\
\hline Hydrosmilodon Flowers \& Domínguez, 1992* & 1 & 0 & 0 & 0 & 1 \\
\hline Massartella Lestage, 1930 & 0 & 0 & 0 & 1 & 1 \\
\hline Needhamella Domínguez \& Flowers, 1989 & 43 & 15 & 39 & 63 & 160 \\
\hline Thraulodes Ulmer, 1920* & 28 & 578 & 303 & 213 & 1122 \\
\hline Ulmeritoides Traver, 1959* & 0 & 0 & 8 & 101 & 109 \\
\hline Ulmeritus Traver, 1956* & 0 & 66 & 373 & 413 & 852 \\
\hline \multicolumn{6}{|l|}{ POLYMITARCYIDAE } \\
\hline Asthenopus Eaton, 1871* & 2 & 0 & 0 & 0 & 2 \\
\hline Campsurus Eaton, 1868 & 68 & 0 & 2 & 1 & 71 \\
\hline Total & 1018 & 2068 & 4920 & 3001 & 11007 \\
\hline
\end{tabular}
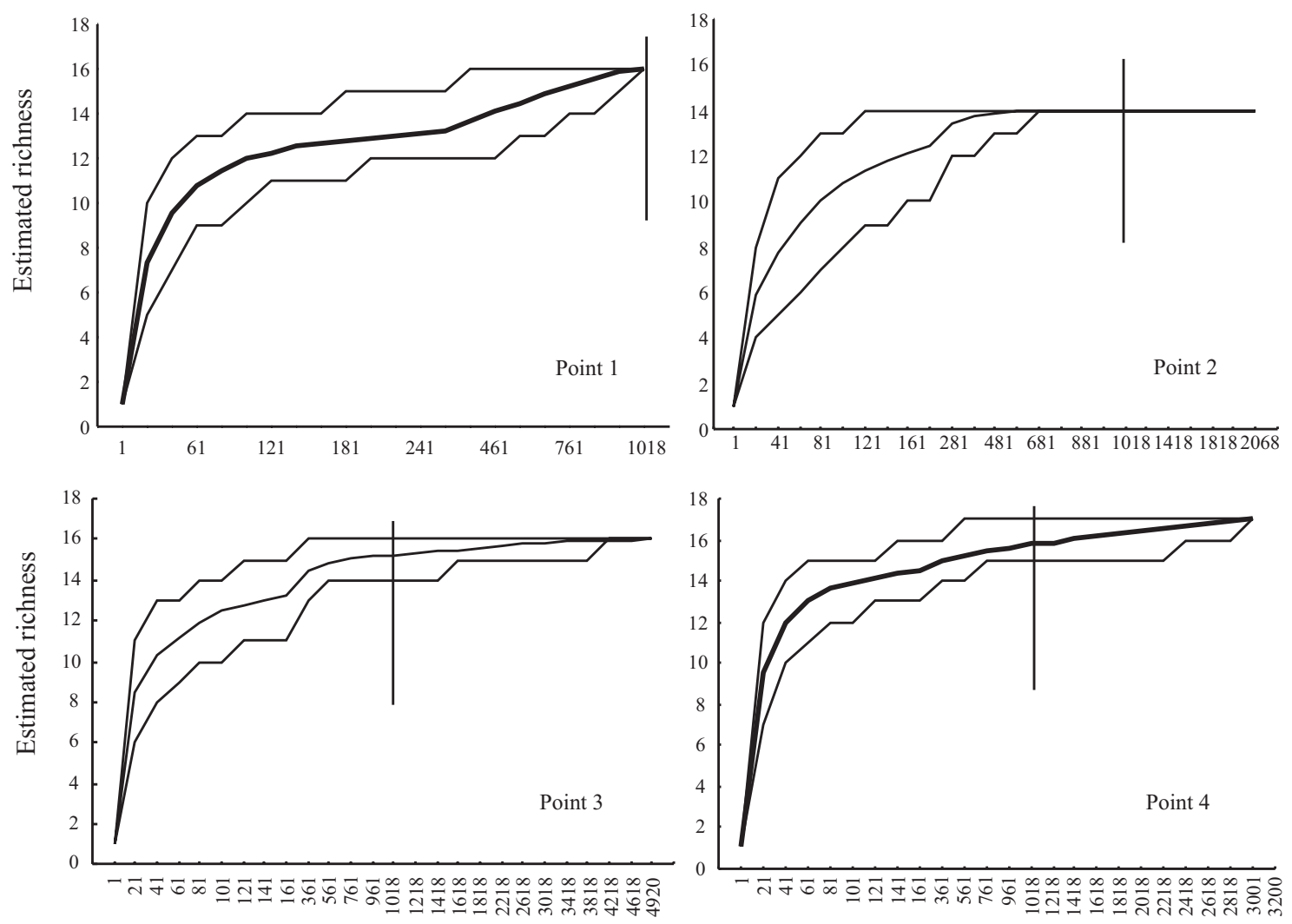

Abundance

Abundance

Fig. 4. Rarefaction curves of Ephemeroptera nymphs genera registered between June 2001 and May 2002 in the Jacuí River middle section and in three tributaries, southern Brazil. The upper and lower lines indicate confidence intervals (95\%) computed for each point, and the bars represent a sub-sample of the 1,018 individuals. 
Table III. Diversity index (H'), Hmax, Evenness (E) and Richness calculated for the four sampled stations and the total of the site in the middle section of the Jacuí River and tributaries, State of Rio Grande do Sul, based from data obtained between June 2001 and May 2002.

\begin{tabular}{lccccc}
\hline Index & Point 1 & Point 2 & Point 3 & Point 4 & Total \\
\hline Shannon-Wiener (H') & 1.98 & 1.69 & 2.24 & $\mathbf{2 . 4 1}$ & 2.47 \\
$\mathrm{H}_{\max }$ & 2.71 & 2.64 & 2.77 & 2.77 & 2.83 \\
Evenness (E) & 0.73 & 0.64 & 0.81 & $\mathbf{0 . 8 7}$ & 0.87 \\
Richness & 16 & 14 & 16 & 17 & 19 \\
\hline
\end{tabular}

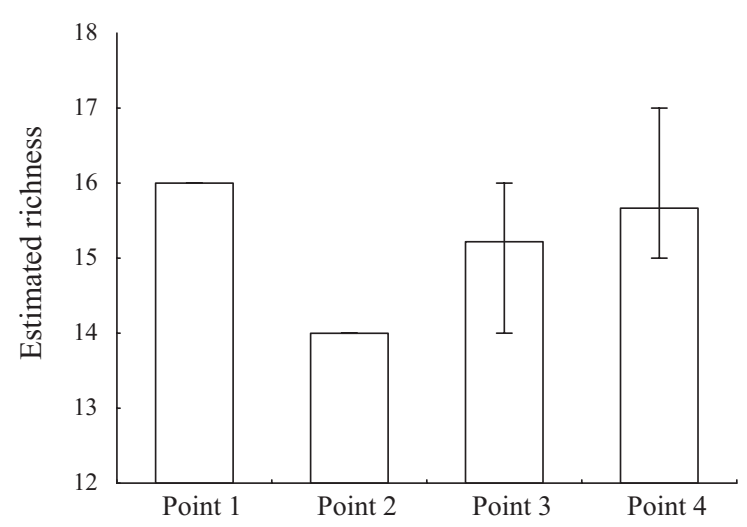

Fig. 5. Estimated richness comparison for 1,018 individuals sampled between June 2001 and May 2002 for Ephemeroptera nymphs assemblages in four sites studied in the Jacuí River and effluents, southern Brazil; for points 3 and 4 the confidence intervals $(95 \%)$ are indicated.
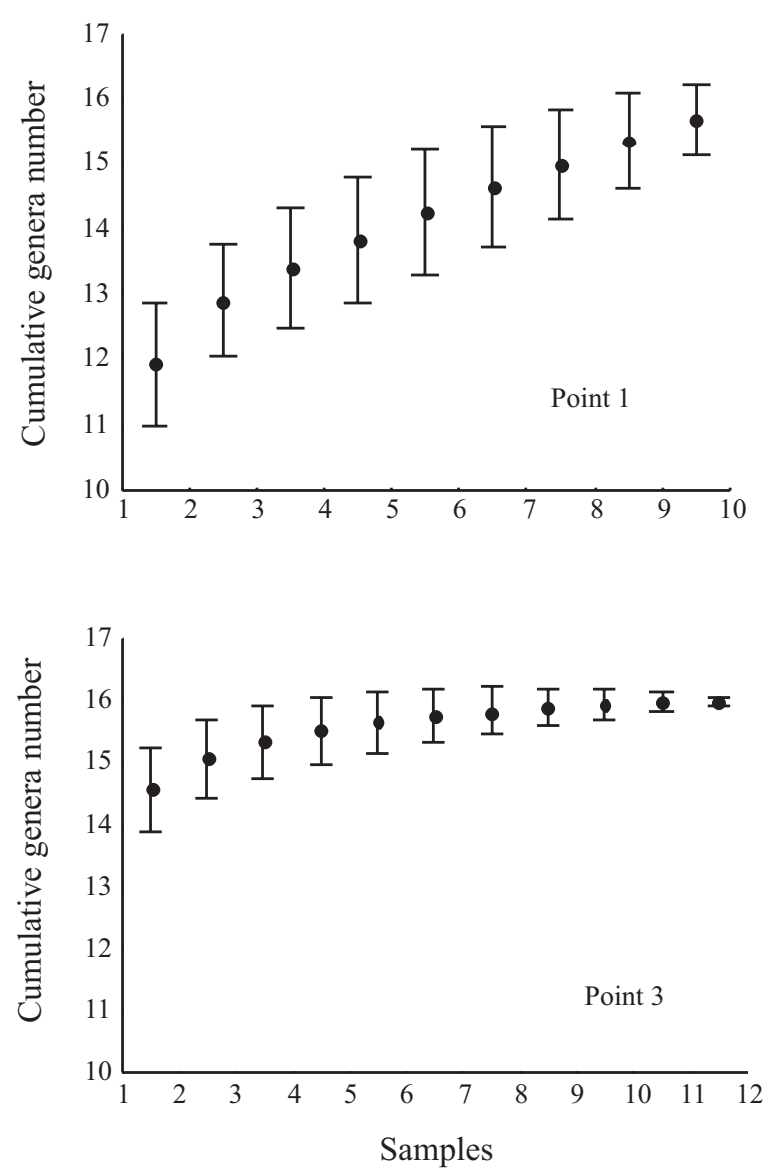

\section{DISCUSSION}

Brazilian Ephemeroptera were, until the 1980s, poorly known in all aspects, taxonomic (HUBBARD, 1982), biological and ecological (e.g., Froenlich, 1969). Since 1990 there has been an increasing number of important contributions, chiefly taxonomic (e.g., DA-SiLVA, 1992; Lopes et al., 2003; Molineri \& Domínguez, 2003). Biological and specially ecological studies are still scarce, what may be due to the lack of faunistic surveys, except for a few isolated ones, in the vast hydrographic system of the country (SALLES et al., 2004b).

Of the 66 genera reported for Brazil, 19 (28.8\%) were collected in the studied area, of which 11 are new records for State of Rio Grande do Sul. Sixteen genera were previously reported for the state (SANTOS, 2003; SALLES et al., 2004b), of which 9 were found in the study area. For the States of Rio de Janeiro and São Paulo, better surveyed, the numbers are 28 and 30 respectively (SALLES et al., 2004b). Three of the four identified species of Leptohyphidae (Leptohyphes plaumanni, Tricorythodes santarita and Tricorythopsis gibbus) are also new records for the state.

The family Leptophlebiidae is widely distributed but attains its maximum diversity in the Southern Hemisphere with the subfamily Atalophlebiinae. In the Neotropics, there are more than 50 described genera and they are a very characteristic element of streams (SAVAGE,
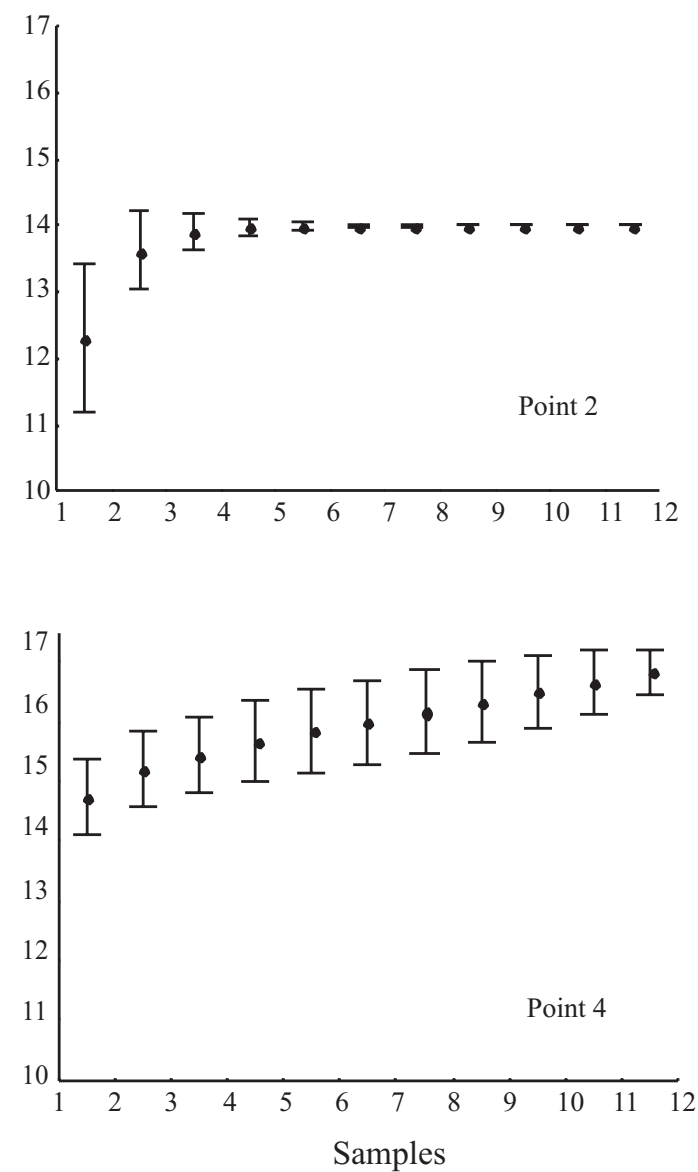

Fig. 6. Accumulation curves of genera for the four Ephemeroptera communities in the middle section of the Jacuí River and tributaries, southern Brazil, built from data obtained between June 2001 and May 2002. The level bars indicate confiance intervals (95\%) computed for each point. 
1987; HubBARD, 1990). In Brazil, Leptophlebiidae and Baetidae are the most numerous families, each with 20 genera ( $61 \%$ of all genera); this is a consequence both of the richness of these families and of the emphasis given to them in taxonomic studies (SAlles et al., 2004b). In this study, the Leptophlebiidae were the most diversified family, with eight genera. Notwithstanding the number of genera of Baetidae occurring in Brazil, only four taxa were found. This may be due to the method used, that sampled predominantly riffles. The genera Baetodes, Cloeodes Traver, 1938 and Camelobaetidius Demoulin, 1966 , found in this study, occurred also in riffles in the Intervales State Park, in the State of São Paulo (Bispo, pers. comm.). Americabaetis, on the other hand, occurs widely in many habitats, including impacted ones.

Leptohyphidae presents six genera in Brazil (DiAs et al., 2005, 2006). Here four genera were collected and the family was the most abundant. Leptohyphidae nymphs are common at the margins of streams, where they live preferentially in depositional areas. In this study, two of the three sampling units were taken at the margins, where water flows slower, allowing a greater deposition of organic matter. Where Podostemum was present, probably the retention of fine organic particles was enhanced, increasing the food supply to these collectorgatherer nymphs. The macrophytes also offer shelter against the water current (EDMUNDs et al., 1976). The presence of these characteristics probably explain the richness and abundance of Leptohyphidae in Points 3 and 4.

Nymphs of all genera collected had a relatively even abundance distribution, except Hydrosmilodon, Massartella and Asthenopus, collected only occasionally. Of these three genera, there is not enough information about Hydrosmilodon; Massartella nymphs are widely distributed and more often found in leaf packs in depositional places (Froenlich \& Oliveira, 1997) while Asthenopus nymphs are burrowers in fallen wood, in roots and in stems of macrophytes, habitats not sampled in this study.

Richness and evenness are key elements in the evaluation of diversity and, with the same richness, communities in which there are no dominant species have a higher diversity. Here the lowest diversity index was obtained in Lajeado do Gringo River (Point 2), that has low values of richness and evenness, the latter due to high numbers of Baetodes. This point is located near a farmstead and is subjected to direct human influence with domestic sewerage and trampling by cattle that causes local instability and a reduction of the riparian vegetation. In this stretch the stream is open to the sunlight, is shallow and suffers organic enrichment, conditions that promote the development of periphyton and favour the dominance of Baetodes, a scraper that lives on the surface of stones (EDMunds et al., 1976).

The largest diversity index was obtained in Carijinho River (Point 4), that presented also the largest richness and evenness. This point has better environmental conditions, better kept riparian trees and more food resources (SPIEs et al., 2006), which permitted the occurrence of a diverse fauna. The presence of a riparian wood and also the presence of macrophytes adhered to the stones probably contributed to give the stretch a higher stability and better offer of food resources. The trees contribute with allochthonous resources and, as the stretch is partially open, the autochthonous primary production is also good. Besides, the macrophytes provide shelter for the animals. It should be noted that this stream receives also sewage effluents upstream, but as it is turbulent and at a sufficient distance, it arrives at the sampling point well selfdepurated.

Looking at the temporal variation in diversity, the sharp fall in November in Point 1 was due to the low abundance and richness, while that in October-November in Point 2 was due to the rise in abundance of Baetodes what decreased evenness and, in consequence, diversity.

The high diversity of mayfly nymphs in the middle course of the Jacuí River, as compared with the theoretical maximum for the area, reflects the high richness and evenness found. According to ConNell (1978), a greater diversity should be found in environments subject to intermediate disturbance level, what would allow the coexistence of a great variety of taxa. HILDREw \& TownSEND (1987) state that these environments, together with a high productivity, permit that highly competitive species but inefficient colonizers coexist with poorly competitive species but good colonizers. In the studied area, disturbance factors such as a sparse riparian vegetation, soil use in the valley, input of organic sewage, although depurated in the studied points, could have enhanced a high productivity and availability of organic particles and as a consequence the high diversity.

Diversity indexes are important for comparing environments, both for an evaluation of their status as for conservation measures, but it is recommended that richness and abundance should be considered separately (Gotelli \& Graves, 1996). Here, to evaluate richness alone, the rarefaction method was used. The rarefaction curves showed, on the whole, a similar expected richness for all points, probably a consequence of the general alteration of the whole region. In spite of local differences such as size of the river, presence of riparian vegetation and anthropic influence, and the fact that some samplings in the 7th order Jacuí River were done in a bay when the river was full, all points were similar as regards substrata and other environmental descriptors. The lower expected richness found in Point 2 mirrors the large local environmental simplification determined by immediate human influence.

Collector curves were worked out to see if the sampling effort was adequate to ascertain the richness of the four points. In Point 2 the curve stabilized, an indication that the sampling effort was adequate. This rarely happens in tropical ecosystems due to their large diversity (S Antos, 2003). The result for Point 2 points to the environmental simplification of the place that does not offer the ecological requirements for a higher diversity. For the other points collector curves showed that a more intensive effort was needed to sample all the fauna, specially for Point 1 , where two distinct spots were sampled, the channel and a bay. Obviously if other mesohabitats besides stony bottoms were sampled, richness would be higher. 
In conclusion, in the studied area mayfly nymph communities presented a high richness, probably a consequence of the availability of food resources. The expected richnesses estimated by the rarefaction method for the four sampling points were on the whole similar, probably a consequence of the alteration and simplification to which the whole region has long been subjected, as well as by the homogeneity of the substrata and environmental factors. Local differences such as size of the river, presence of riparian vegetation and anthropic impact were not important enough to cause differences in the composition of genera. Point 4 , however, with its better environmental conditions and a slightly higher diversity, may be showing a dampening of the impacts.

Acknowledgments. To DFESA (Dona Francisca Energética S.A) for financial support in the sampling. To $\mathrm{CNPq}$ (Conselho Nacional de Desenvolvimento Científico e Tecnológico) for student fellowship to the senior author. To MSc. Marcia Spies and the biologist Damaris Neri for assistance during the collections and sorting the material. To Dr. Pitágoras da Conceição Bispo (UNESP-Assis) and Dr. Elidiomar Da-Silva (UFRJ) for valuable comments on the manuscript. To MSc. Lucimar Dias for assistance in the identification of the Leptohyphidae species. To Dr. João Fernando Prado (UFRGS) for macrophyte identification. To anonymous reviewer and Marcos Callisto de Faria Pereira for suggestions on the manuscript.

\section{REFERENCES}

Ayres-Peres, L.; Sokolowicz, C. C. \& Santos, S. 2006. Diversity and abundance of the benthic macrofauna in lotic environments from the central region of Rio Grande do Sul State, Brazil. Biota Neotropica 6(3):1-10

Baptista, D. F.; Dorvillé, L. F. M.; Buss, D. F. \& Nessimian, J. L. 2001. Spatial and temporal organization of aquatic insects in the longitudinal gradient of a tropical river. Revista Brasileira de Biologia 61(2):295-304.

Baptista, D. F.; Buss, D. F.; Dias, L. G.; Nessimian, J. L.; Da Silva, E. R.; De Moraes Neto, A. H. A.; Carvalho, S. N.; Oliveira, M. A. \& Andrade, L. R. 2006. Functional feeding groups of Brazilian Ephemeroptera nymphs ultrastructure of mouthparts. Annales de Limnologie 42(2):87-96.

Bispo, P. C.; Oliveira, L. G.; Crisci, V. L. \& Silva, M. M. 2001. A pluviosidade como fator de alteração da entomofauna bentônica (Ephemeroptera, Plecoptera e Trichoptera) em córregos do Planalto central do Brasil. Acta Limnologica Brasiliensia 13(2):1-9.

Bueno, A. P.; Bond-Buckup, G. \& Ferreira, B. D. P. 2003. Estrutura da comunidade de invertebrados bentônicos em dois cursos d'água do Rio Grande do Sul, Brasil. Revista Brasileira de Zoologia 20(1):115-125.

Coleman, B. D. 1981. On random placement and species-area relations. Mathematical Biosciences 54:191-215.

Colwell, R. K. 2004. EstimateS: statistical estimation of species richness and shared species from sample, version 7.0. Available at: <http://viceroy.eeb.uconn.edu/ estimates>. Access on: 24.10.2004.

Colwell, R. K. \& Coddington, J. A. 1994. Estimating terrestrial biodiversity through extrapolation. Philosophical Transactions of the Royal Society of London, B 345: 101-118.

Connell, J. 1978. Diversity in tropical rainforest and coral reefs. Science 199:1302-1310.

DA-Silva, E. R. 1992. Description of the nymph of Homoeoneuria (Notochora) fitkaui Pescador \& Peters, 1980 from northeastern Brazil (Ephemeroptera, Oligoneuriidae, Oligoneuriinae). Revista Brasileira de Entomologia 36(3):693-696

Dias, L. G.; Salles, F. F. \& Molineri, C. 2005. Macunahyphes: a new genus for Tricorythodes australis (Ephemeroptera: Leptohyphidae). Annales de Limnologie 45(3):195-201.
Dias, L. G.; Salles, F. F.; Francischetti, C. N. \& Ferreira, P. S. F. 2006. Key to the genera of Ephemerelloidea (Insecta: Ephemeroptera) from Brazil. Biota Neotropica 6(1):1-6.

Domínguez, E.; Molineri, C.; Pescador, M.; Hubbard, M. \& Nieto, C. 2006. Ephemeroptera of South America. In: AdIs, J.; Arias, J. R.; Rueda-Delgado, G. \& Wantzen, K. M. eds. Aquatic Biodiversity in Latin America (ABLA), v.2. Sofia Moscow, Pensoft. 646p.

Durlo, M. A.; Marchiori, J. N. C. \& Longhi, S. J. 1982. Composição e estrutura da mata secundária no vale do Rio Jacuí, RS. Ciência \& Natura 4:129-139.

Edmunds JR., G.; Jensen, S. L. \& Berner, L. 1976. The Mayflies of North and Central America. Minneapolis, University of Minnesota. 330p.

Froenlich, C. G. 1969. Caenis cuniana sp. n., a parthenogenetic mayfly. Beiträge Zur Neotropischen Fauna 6(2):103-108.

Froenlich, C. G. \& Oliveira, L. G. 1997. Ephemeroptera and Plecoptera nymphs from riffles in low-order streams in southeastern Brazil. In: LANDOLT, P. \& SARTORI, M. orgs. Ephemeroptera \& Plecoptera: Biology-EcologySystematics. Fribourg. p.180-185.

Gotelli, N. J. \& Entsminger, G. L. 2003. EcoSim: Null Models Software for Ecology. Version 7.0 Acquired Intelligence Inc. \& Kesey-Bear. Available at: <http://homepages.together net gentsmin/ecosim.htm>. Access on: 01.12.2005.

Gotelli, N. J. \& Graves, G. R. 1996. Null Models in Ecology Washington, Smithsonian Institution. 368p.

Hammer, O.; Happer, D. A. T. \& Ryan, P. D. 2003. PAST: Paleontological Statistics software package for education and data analysis. Paleontologia Eletronica 4(1):1-9.

HildRew, A. G. \& Townsend, C. R. 1987. Organization in freshwater benthic communities. In: Gee, J. H. R. \& Giller, P. S. eds. Organization of Communities: Past and Present. Oxford, Blackwell Scientific Publications. p.347-371.

Hubbard, M. D. 1982. Catálogo abreviado de Ephemeroptera da América do Sul. Papéis Avulsos de Zoologia 34(24):257-282. 1990. Mayflies of the world: a catalog of the family and genus group taxa (Insecta: Ephemeroptera). Gainesville, Flora \& Fauna Handbook 8. Sandhill Crane. 119p.

HuRlBert, S. H. 1971. The nonconcept of species diversity: a critique and alternative parameters. Ecology 52:577-585.

Krebs, C. J. 1999. Ecological Methodology. Menlo Park, CA, Addison Wesley Longman. 620p.

Longhi, S. J.; Durlo, M. A. \& Marchiori, J. N. C. 1982. A vegetação da mata ribeirinha no curso médio do rio Jacuí, RS Ciência \& Natura 4:151-161.

Lopes, M. J. N.; Froehlich, C. G. \& Domínguez, E. 2003. Description of the larva of Thraulodes schlingeri (Ephemeroptera, Leptophlebiidae). Iheringia, Série Zoologia, 93(2):197-200.

Maluf, G. R. T. 2000. Nova classificacão climática do Rio Grande do Sul. Revista Brasileira de Agrometeorologia 8(1): $141-150$

Marchiori, J. N. C.; Longhi, S. J. \& Durlo, M. A. 1982. A vegetação de capoeira na região do curso médio do rio Jacuí, RS. Ciência \& Natura 4:141-150.

Marcuzzo, S.; Pagel, S. M. \& Chiappetti, M. I. S. 1998. A Reserva da Biosfera da Mata Atlântica no Rio Grande do Sul: Situação Atual, Ações e Perspectivas. São Paulo, Consórcio da Mata Atlântica e Conselho Nacional da Reserva da Biosfera da Mata Atlântica (caderno 11). 60 p.

McAlecee, N.; Lambsheah, P. J. D.; Paterson, G. L. J. \& Gage, J. G. 1997. BioDiversity Professional. Beta-Version. London, The Natural History Museum and the Scottish Association for Marine Sciences

Melo, S. M.; TAKedA, A. M. \& Monkolski, A. 2002. Seasona dynamics of Callibaetis willineri (Ephemeroptera, Baetidae) associated with Eichhornia azurea (Pontederiaceae) in Guarana Lake of the Upper Parana River, Brazil. Hydrobiologia 470:57-62.

Merritt, R. W. \& Cummins, K. W. 1996. An Introduction to the Aquatic Insects of North America. 3.ed. Dubuque, Iowa, Kendall/ Hunt. 862p.

Molineri, C. \& Domínguez, E. 2003. Nymph and egg of Melanemerella brasiliana (Ephemeroptera: Ephemerelloidea: Melanemerellidae), with comments on its systematic position and the higher classification of Ephemerelloidea. Journal of the North American Benthological Society 22(2):263-275. 
Neri, D. B.; Kotzian, C. B. \& Siegloch, A. E. 2005. Composição de Heteroptera aquáticos e semi-aquáticos na área de abrangência da U.H.E. Dona Francisca, RS, Brasil: fase de pré-enchimento. Iheringia, Série Zoologia 95(4):421-429.

Oliveira, L. G. \& Froehlich, C. G. 1997. Diversity and community structure of aquatic insects (Ephemeroptera, Plecoptera and Trichoptera) in a southeastern Brazilian mountain stream. Acta Limnologica Brasiliensia 9:139-148.

Oliveira, L. G.; Bispo, P. C. \& Sá, N. C. 1997. Ecologia de comunidades de insetos bentônicos (Ephemeroptera, Plecoptera e Trichoptera) em córregos do Parque Ecológico de Goiânia, Goiás, Brasil. Revista Brasileira de Zoologia 14(4):867-876.

Oliveira, L. G.; Bispo, P. C.; Crisci, V. L. \& Sousa, K. G. 1999. Distribuições de categorias funcionais alimentares de larvas de Trichoptera em uma região serrana do Brasil Central. Acta Limnologica Brasiliensia 11(2):173-183.

Pereira, P. R. B.; Netto, L. R. G. \& Borin, C. J. A. 1989. Contribuição à geografia física do município de Santa Maria: Unidades de paisagem. Geografia-Ensino \& Pesquisa 3:37-68.

Polegatto, C. M. \& Batista, J. D. 2007. Hydromastodon sallesi, new genus and new species of Atalophlebiinae (Insecta: Ephemeroptera: Leptophlebiidae) from West and North of Brazil, and notes on systematics of Hermanella group. Zootaxa 1619:53-60.

Poole, R. W. 1974. An Introduction Quantitative Ecology. New York, McGraw-Hill. 532p.

Salles, F. F.; Da-Silva, E. R.; Serrão, J. E. \& Francischetti, C. N. 2004a. Baetidae (Ephemeroptera) na Região Sudeste do Brasil: novos registros e chave para os gêneros no estágio ninfal. Neotropical Entomology 33(5):569-576.

Salles, F. F; Da-Silva, E. R; Serrão, J. E; Hubbard, M. D. \& Francischetti, C. N. 2004b. As espécies de Ephemeroptera (Insecta) registradas para o Brasil. Biota Neotropica
4(2): <http: www.biotaneotropica.org.br/v $4 \mathrm{n} 2 / \mathrm{pt} /$ abstract?inventory+BM04004022004>. Access on: 12.10.2004

Santos, A. J. 2003. Estimativas de riqueza em espécies. In: CulleN Jr., L.; Rudram, R. \& Valladares-Padua, C. orgs. Métodos de Estudos em Biologia da Conservação e Manejo da Vida Silvestre. Curitiba, UFPR, Fundação Boticário de Proteção à Natureza. p.19-41.

Santos, E. M.; Stenert, C.; Oliva, T. D. \& Maltchiк, L. 2003. Estabilidade de macroinvertebrados em uma lagoa associada a uma planície de inundação do Rio dos Sinos (RS-Brasil). Acta Biologica Leopoldensia 25:205-219.

Savage, H. M. 1987. Biogeographic classification of the Neotropical Leptophlebiidae (Ephemeroptera) based upon geological centers of ancestral origin and ecology. Studies on Neotropical Fauna and Environmental 22(4):199-222.

Siegloch, A. E.; Polegatto, C. M. \& Froehlich, C. G. 2006. Segesta riograndensis, new genus and species of Atalophlebiinae mayfly from South of Brazil (Ephemeroptera: Leptophlebiidae). Zootaxa 1299:35-43.

SimberlofF, D. 1972. Properties of the rarefaction diversity measurement. American Naturalist 106:414-418.

Spies, M. R.; Froehlich, C. G. \& Kotzian, C. B. 2006. Composition and diversity of Trichoptera (Insecta) larvae communities in the middle section of the Jacuí River and some tributaries, State of Rio Grande do Sul, Brazil. Iheringia, Série Zoologia, 96(4):389-398.

Stenert, C.; Santos, E. M.; Oliva, T. D. \& Maltchik, L. 2002. Diversidade de macroinvertebrados em áreas úmidas na bacia do rio dos Sinos, RS, Brasil. Acta Biologica Leopoldensia 24(2): 157-1172.

Strahler, H. N. 1957. Quantitative analysis of watershed geomorphology. American Geophysical Union Transactions 33:913-920. 